\title{
PERLAKUAN AKUNTANSI DAN PELAPORAN PERTANGGUNG JAWABAN SOSIAL PERUSAHAAN PT. PLN (PERSERO) P3BJB APP SURABAYA
}

\author{
Abdul Ghofur \\ Fakultas Ekonomi, Universitas Islam Lamongan
}

\begin{abstract}
ABSTRAK
Peneliti ini menganalisis perlakuan akuntansi dan pelaporan tanggung jawab sosial pada PT. PLN (Persero) P3BJB APP Surabaya. Permasalahan yang ingin diketahui yaitu pelakuan akuntansi dan pelaporan program CSR, apakah penerapkan sesuai UU No. 40 tahun 2007 perseroan terbatas tentang Tanggang Jawab Sosial Dan Lingkungan, apakah pelaporan keuangan perusahahaan sesuai dengan PSAK 01. Dengan menggunakan metode wawancara dan observasi dalam memperoleh data dan informasi untuk di analisis. Berdasarkan hasil penelitian PT. PLN (Persero) P3BJB APP Surabaya mengelola CSR dengan dasar peraturan Undang-Undang No 40 tahun 2007, Perseroan Terbatas Pasal 74 tentang Tanggung Jawab Sosial dan Lingkungan. Sedangkan Program CSR secara keseluruan dilaporkan sebagai beban pada laporan keuangan utama perseroan, dalam laporan laba-rugi diklasifikasikan dalam pos beban lain-lain dengan nama ComDev (Community Development). Laporan keuangan perusahaan telah sesuai dengan PSAK 01, penyajian laporan keuangan. aktivitas CSR PT. PLN (Persero) juga dilaporkan dalam Sustainability Report dalam bentuk Narative Reporting. Dari hasil penelitian diatas bahwa PT. PLN (Persero) P3BJB APP Surabaya telah melakukan pelakuan akuntansi sesuai dengan PSAK dan pelaporan CSR sesuai dengan UU No. 40 tentang Tanggung Jawab Sosial Perusahaan dan Lingkungan.
\end{abstract}

Kata kunci: Corporate Sosial Responsibility (CSR), Sustainability Report, Community Development (ComDev), UU No 40 tahun 2007 perseroan terbata, PSAK 01 .

\section{PENDAHULUAN}

Suatu perusahaan yang berdiri tentunya memiliki suatu tujuan atas kegiatan yang di lakukannya baik menghasilkan maupun menguntungkan sebagai suatu bentuk pelayanan publik.Sehingga perusahaan berdiri bukan tanpa tujuan dan tanpa memberikan manfaat kepada berbagai pihak. Untuk mencapai semua itu diperlukan suatu upaya bersama dan dukungan dari berbagai pihak yaitu karyawan dan masyarakat di sekitar perusahaan, selain itu juga bagaimana perusahaan memperlakukan kepatuhan kepatuhan akuntansi pertanggung jawaban sosial. dimana menurut pendekatan teori akuntansi tradisional, 
perusahaan harus memaksimalkan labanya agar dapat memberikan sumbangan yang maksimum kepada masyarakat (Luhgiatno, 2007). Akan tetapi, masyarakat pun sadar akan dampak-dampak yang di timbulkan dari kegiatan operasinya sehingga perusahaan harus memperhatikan dampak yang ditimbulkan dan turut serta menjaga dan perduli terhadap lingkungan sekitar masyarakat sebagai Stakeholder dengan mengadakan aktivitas sosial sebagai bentuk pertanggung jawaban sosial perusahaan terhadap lingkungan sekitar yang biasa disebut Corporate Social Responcibility (CSR) (Aini dan Andayani, 2013).

Tanggung jawab sosial perusahaan dimplementasikan kepada seluruh Stakeholders, yang mengakomodasikan kebutuhan dan kepentingannya timbul sejak adanya kesadaran akan keberlanjutan perusahaan dalam jangka panjang yang ternyata lebih penting dari pada peningkatan keuntungan perusahaan semata. CSR adalah suatu bentuk kepedulian organisasi bisnis untuk bertindak dengan cara-cara mereka sendiri dalam melayani kepentingan organisasi dan kepentingan publik eksternal (Schermerhorn dalam Hapsari, 2012). Secara konseptual, CSR adalah Pendekatan dimana perusahaan mengintergrasikan kepedulian sosial dalam operasi bisnis dan interaksi perusahaan dengan para pemangku kepetingan (Stekeholder) berdasarkan prinsip sukarelaan dan kemitraan (Nueryana dalam Hapsari, 2012). Dasardasar pertimbangan yang menentang pertanggung jawabban sosial diantaranya menghambat upaya maksimalisasi laba, mengaburkan tujuan perusahaan dan sebagainya, namun di pihak lain terdapat berbagai dasar pemikiran yang mendukung perlunya operasionalisasi tanggung jawab sosial (Widaryanti, 2007).

Respon sibilititas perusahaan dilaporkan melalui Sustainability Report menurut Sukada dalam Yulfajar (2013) Sustainnability Report, sebagai salah satu bentuk laporan bentuk tunggal adalah laporan kinerja perusahaan yang berkaitan dengan pencapaian tujuan pembangunan berkelanjutan. Salah satu indikator bahwa suatu informasi akuntansi relevan adalah adanya reaksi pemodal pada saat diumumkanya informasi yang dapat diamati dari pergerakan harga saham, informasi yang dapat di gunakan untuk mengambil keputusan tersebut adalah laba akuntansi. Di pilihnya PT. (Perusahaan Listrik Negara) PLN Perseroan sebagai 
obyek penelitian atas dasar pertimbangan bahwa listrik merupakan infrastruktur yang penting bagi kualitas hidup manusia juga sebagai penunjang berbagai kegiatan perekonomian (Handayanni, 2008 dalam Putra, 2013). Oleh karena itu penulis tertarik mengadakan penelitian mengetahui bagaimana perlakuan akuntansi dan pelaporan pertanggung jawaban sosial perusahaan yang di lakukan PT. Perusahaan Listrik Negara (Persero) Penyaluran dan pusat pengatur Beban Jawa Bali Area Pelaksana Pemeliharaan Surabaya (PT. PLN persero P3BJB APP Surabaya).

Adapun tujuan dari penelitian ini adalah untuk mengetahui apakah PT. PLN (Persero) P3BJB APP Surabaya telah melaporkan tanggung jawab sosialnya sesuai Undang-Undang No. 40 Tahun 2007, Perseroan Terbatas Pasal 74 tentang Tanggung Jawab Sosial dan Lingkungan dan untuk mengetahui apakah PT. PLN (Persero) P3BJB APP Surabaya menyajikan laporan mengenai tangung jawab sosial diluar Laporan Keuangan Utama seperti yang disebutkan dalam PSAK No.01 tentang Penajian Laporan Keuangan.

\section{TINJAUAN PUSTAKA}

\subsection{Tanggung Jawab Sosial Perusa- haan}

Menurut Burdiarsi (2005) dalam Rajafi dan Irianto (2007) menunjukkan beberapa definisi mengenai tanggung jawab sosial perusahaan yang dikemukakan oleh beberapa penelitian sebelumnya antara lain:"tanggung jawab sosial perusahaan merupakan praktek bisnis transparan, yang didasarkan pada nilai-nilai etika, dengan memberikan perhatian pada karyawan, masyarakat dan lingkungan, serta dirancang untuk dapat melestarikan masyarakat secara umum dan juga para pemegang saham (CSRwire, 2005)". Tanggung jawab sosial perusahaan memiliki empat jenis tanggung jawab, yaitu yang bersifat ekonomis, artinya memperoleh laba bagi pemegang saham; legal, mematuhi peraturan dan hukum (berhubungan dengan lingkungan dan sebagainya); etika atau ethical dimana perusahaan harus memenuhi kaidah -kaidah normatif seperti berlaku jujur, transparan, tidak ada diskriminasi ras atau gender dan tidak korupsi.Legitimasi merupakan hal yang penting bagi aksistensi sebuah perusahaan. sehingga berbagai upaya dilakukan perusahaan untuk memperoleh legitimasi. Organisasi berusaha 
memastikan bahwa kegiatan yang mereka lakukan diakui (legitimate) oleh pihak luar yaitu dengan cara perusahaan beroperasi sesuai batasan-batasan dan norma atau nilai yang berlaku. Perusahaan seharusnya sadar bahwa keberlangsungan hidup perusahaan tergantung dari hubungan perusahaan dengan lingkungan sosial nya. Dalam petukaran yang terjadi antara perusahaan dan lingkungan sosialnya terdapat dua dampak yang timbul, yaitu dampak positif dan dampak negatif. Masalah yang timbul adalah bagaimana mengukur kedua dampak tersebut sebagai Social Cost dan Social Benefit (Luhgiatno, 2007). Zulfikar (1997) dalam Luhgiatno (2007) mengusulkan beberapa teknik pengukuran manfaat dan biaya sosial yaitu. 1. Penilaian pengganti (Surrogate Valuation). Jika nilai dari sesuatu tidak dapat secara langsung ditemukan, maka kita dapat mengetimasikannya dengan nilai suatu pengganti, yaitu sesuatu yang kira-kira mempunyai kegunaan yang sama dengan yang sedang diukur. 2. Teknik survey (survey techniques). Survey dilakukan dengan mengobservasi secara langsung kepada pihak-pihak yang berhubungan dengan dampak usaha dari perusahaan terkait bentuk pertanggung jawaban seperti apa yang diinginkan.

Akuntansi dengan pelaporan keuangan sebagai produk utamanya diharapkan dapat membantu perusahaan dalam mengungkapkan dan melaporkan tanggung jawab sosial perusahaan sebagai bentuk kepedulian perusahaan sebagai bentuk kepedulian perusahaan terhadap lingkungan sosialnya (Winartie dan Sujono dalam Putra, 2013).

\subsection{Laporan Keuangan}

Laporan keuangan pada dasarnya adalah hasil dari proses akuntansi yang dapat digunakan sebagai alat untuk mengkomunikasikan data keuangan atau aktivitas perusahaan kepada pihakpihak yang berkepentingan. Pihak-pihak yang berkepentingan terhadap posisi keuangan maupun perkembangan perusahaan dibagi menjadi dua, yaitu pihak internal seperti manajemen perusahaan dan karyawan, dan yang kedua adalah pihak eksternal seperti investor, kreditur, pemerintah, dan masyarakat (Hery, 2008). Menurut PSAK No. 1 (revisi 2013 ) laporan keuangan adalah suatu penyajian terstruktur dari posisi keuangan dan kinerja keuangan suatu entitas. Menurut PSAK No. 1, (revisi 2013) Tujuan 
laporan keuangan adalah memberikan informasi mengenai posisi keuangan, kinerja keuangan dan arus kas entitas yang bermanfaat bagi sebagian besar pengguna laporan keuangan dalam pembuatan keputusan ekonomi.

\section{METODOLOGI PENELITIAN}

Jenis penelitian ini merupakan penelitian kualitatif deskriptif analisis yaitu penelitian yang dimaksudkan untuk memberikan penjelasan dan gambaran tentang penelitian tersebut. populasi penelitian ini adalah pelakuan akuntansi dan pelaporan pertanggung jawaban sosial PT. PLN (persero) P3BJB APP Surabaya. Sampel yang di ambil dalam penelitian ini adalah penerapan pelakuan akuntansi dan pelaporan pertanggung jawaban sosial. Dengan menggunakan teknik pengambilan sampel berupa analisi terhadap pengakuan, pengukuan, pengungkapan, pelaporannya. Populasi dari peneliti ini adalah keseluruan dari kegiatan operasional perusahaan.

\section{HASIL PENELITIAN DAN PEMBAHASAN}

PT. PLN (Persero) sebagai sebuah perseroan, dimana juga memiliki kewajiban melakukan tanggung jawab sosial sebagaimana telah diatur dalam
Undang-Undang No. 40 tahun 2007 tentang Perseroan Terbatas. Dalam laporan keuangan utama PT. PLN (Persero) P3BJB APP Surabaya, memang tidak ada laporan tambahan yang khusus terkait dengan tanggung jawab sosial perusahaan.

Laporan keuangan perseroan yang disusun lengkap beserta CALK dilakukan oleh PLN Pusat. PLN Unit dan area hanyak menyusun summary dari laporan keuangan. selanjutnya dikirim ke kantor tingkat di atasnya untuk diperiksa, kemudian diberikan ke pusat untuk disusun laporan keuangan laporan konsolidasinya. Sehingga format laporan keuangan lengkap beserta CALK disusun oleh PLN Pusat.

Seperti yang telah dijelaskan sebelumnya, bahwa informasi yang mampu menunjukkan telah dilakukan tanggung jawab sosial oleh PT. PLN (Persero) dalam laporan keuangan utama perusahaan dapat kita lihat pada laporan laba rugi. Dalam laporan tersebut terdapat akun beban lain-lain yang didalamnya terdapat akun CSR telah di lakukan yang disebut dengan ComDev (Comumunity Development). PT. PLN (Persero) P3BJB APP Surabaya telah menaati, menerapkan dan melakukan, sesuai dalam UU NO. 40 tahun 2007 
tentang Tanggung Jawab Sosial Dan Lingkungan, dengan program yang dilakukan yaitu: 1. Memberikan bantuan berupa pralatan pratikum madrasah tsanawiyah al-muttaqim. 2. Memberikan bantuan hand tractor kepada kelompok tani "intisari"

Sedangkan program kemitraan dan bina lingkungan di APP tidak ada. yang ada dan telah berjalan yaitu program tanggung jawab sosial perusahaan yang sering di sebut dengan CSR ( Corporate Social Responsibility . Telah dilihat laporan keuangan PT. PLN (Persero) telah sesuai dengan PSAK 01 pragraf 09 (revisi 2015) yaitu "laporan keuangan adalah suatu penyajian tersetruktur dari posisi keuangan dan kinerja keuangan suatu entitas.

\section{PENUTUP}

\subsection{Simpulan}

Dari pembahasan yang telah di jelaskan dalam bab sebelumnya maka dapat diperoleh kesimpimpulan sebagai berikut: 1. Implementasi tanggung jawab sosial PT. PLN (Persero) P3BJB APP Surabaya bisa di katakan sudah baik. Beberapa program diantaranya adalah BUMN yang di realisasikan di area surabaya dengan tujuan untuk meningkatkan proses belajar mengajar serta menunjang keberhasilan bagi siswa-siswi dan di Madura dengan tujuan untuk meningkatkan taraf hidup dan meningkatkan ekonomi keluarga untuk menunjang keberhasilan bagi warga sekitar.

Selain dilaporkan dalam bentuk laporan posisi keuangan dan laporan aktivitas yang terpisah dari laporan keuangan utama perusahaan serta mencantum sebagai beban dalam laporan laba-rugi perusahaan, PT. PLN (Persero) juga mengungkapkan kegiatan tanggung jawab sosialnya dalam laporan keberlanjuttan (Sustainability Report). Laporan keberlanjutan tersebut disusun oleh kantor pusat PT. PLN (Persero). 2. Untuk penerapan program Corporate Social Responsibility PT. PLN (Persero) P3BJB APP Surabaya telah mematuhi bentuk kepatuan perseroan dalam memenuhi UU No. 40 tahun 2007 tentang perseroan terbatas untuk melaksanakan tanggung jawab sosial. Dilaksanakan tanggung jawab sosial PT. PLN (Persero) P3BJB APP Surabaya terlihat pada laporan laba-rugi yang digolongkan pada bagian beben lain-lain dan pos beban itu di sebut ComDev (Community Development). Diakui beban karena dianggap tidak memiliki nilai ekonomis kedepannya dan 
merupakan pengeluaran diluar operasi utama perusahaan, sehingga murni untuk program tanggung jawab sosialnya. penyaluran dana bersumber dari usulan program dari unit PLN dan dari eksternal (SOP No. CSR/01/2012). Sedangkan di PT. PLN(Persero) P3BJB APP Surabaya hanyak melaksanakan program CSR. Laporan keuangan perusahaan telah sesuai dengan standar PSAK 01 yang berlaku.

\subsection{Saran}

Berdasarkan kesimpulan yang diperoleh, serta keterbatasan dari penelitian ini maka peneliti mencoba memberi saran yang sekiranya bermanfaat yaitu: Disarankan agar perusahaan tetap membuat laporan terpisah mengenai realisasi kegiatan agar lebih mudah mengevaluasi kegiatan atau program yang berjalan serta berguna untuk pertimbangan program yang akan dilaksanakan. Untuk penelitian selanjutnya yang akan meneliti di bidang tanggung jawab sosial obyek penelitian serupa, disarankan menggunakan PT. PLN (Persero) pusat sebagai obyek penelitiannya agar memperoleh gambaran lebih jelas terkait kebijakan perusahaan.

\section{DAFTAR PUSTAKA}

Aini, N dan Andayani. 2013. Tanggung Jawab Sosial Perusahaan: Bentuk Aktivitas dan Laporan Akuntansi, Studi Kasus pada PT. Garam (persero). Jurnal Ilmu dan Riset Akuntansi. Vol.1 No. 2.

Hapsari N. 2012. Program Kemitraan dan Bina Lingkungan sebagai Strategi Pembentukan Citra Perusahaan sebagai Program Coprporate Sosial Responsibility PT. Petrokimia Gresik.

Hery, 2008. Pengantar Akuntansi 1. Jakarta: LP- FEUI.

Luhgiatno. 2007. Akuntansi Sosial Bentuk Kepedulian Perusahaan Terhadap Lingkungan ( Sosial Accounting Is A Attention Corparate Model By Environ)

PSAK 01. Penyajian Laporan Keuangan (revisi 2009).

Putra. 2013. Analisis Perlakuan Akuntansi dan Pelaporan Pertanggung Jawaban Sosial Perusahaan.

Rajafi, R dan Irianto, G . 2007. Analisis Pengungkapan Laporan Sosial 
dan Lingkungan dalam

Akuntansi Pertanggung Jawaban

Sosial Perusahaan. Tema. Vol: 8, No: 1.

Sustainability Report . 2013.

Undang - Undang Republik Indonesia Nomer 40 Tahun 2007 ,tentang Perseroan Terbatas.

Yulfajar, A. 2013. Analisis Tingkat Kepatuan Pengungkapan CSR Oleh Perusahan Pertambangan Yang Terdaftar Di Bursa Efek Indonesia. Media Mahardhika Vol.11 No. 3: 47-92.

Widaryanti. 2007. Analisis Pengaruh Pengungkapan Tanggung Jawab Sosial Perusahaan Terhadap Kinerja Keuangan (Studi Pada Perusahaan Yang Terdaftar Di Bursa Efek Jakarta ); Issn : 1907 - 6304, Fokus Ekonomi Vol.2 No.2: $30-50$. 